\title{
ADOLESCENTS' SENSE OF COHERENCE VS COPING IN STRESSFUL SITUATIONS. PILOT STUDY ${ }^{1}$
}

\author{
Karol Konaszewski \\ University of Bialystok, Poland \\ Wioleta Danilewicz \\ University of Bialystok, Poland \\ Tomasz Sosnowski \\ University of Bialystok, Poland
}

\begin{abstract}
The objective of the article is the answer to the question if the level of the sense of coherence is linked with stress-coping styles in the group of subjects. It was assumed that in the group of youth the sense of coherence would positively correlate with stress-coping strategies based on problem-solving and looking for social contacts, whereas negatively with strategies based on emotion display (Płaczkiewicz \& Tucholska, 2009). The study was conducted on a group of 149 teenagers of both sexes, aged 14-18 years. The research employed the Life Orientation Questionnaire (SOC-29) by A. Antonovsky and the Coping Inventory for Stressful Situations (CISS) Questionnaire by N. S. Endler and J. D. A Parker. In the group of youth, correlation coefficients indicate a moderate, positive relationship of the sense of coherence and a sense of comprehensibility with a task-focused style. There was also a positive correlation between the general sense of coherence (and three components: a sense of comprehensibility, a sense of manageability and a sense of meaningfulness) and looking for social contacts. Statistically significant correlation coefficients were also obtained between the emotionfocused style and the general sense of coherence and its two components. The results of this study have important implications. They allow for a better understanding of the sense of coherence that contribute to the stress-coping styles among youth. Future interventions could be based on the strengthening of sense of coherence in analyzed group.
\end{abstract}

Keywords: sense of coherence, youth, adolescents, stress, coping.

\section{Introduction}

The concept of salutogenesis by A. Antonovsky (1995), in which the key necessary factor for effective coping with stressors is the high sense of coherence, plays an important role in coping with stress. Strong sense of coherence makes us

\footnotetext{
${ }^{1}$ Study financed by the National Science Centre, Poland no.: 2015/17/N/HS6/02900. Research project carried out as part of the PRELUDIUM 9 contest.

(C) Rēzeknes Tehnologiju akadēmija, 2017

http://dx.doi.org/10.17770/sie2017vol3.2333
} 
activate resources appropriate in the situation we face and enables us to use them to the full. Salutogenetic orientation suggests approaching health and disease as a continuum, with the present position of a person depending on the strength of their sense of coherence (Dolińska-Zygmunt, 2001). The sense of coherence is "a global orientation that expresses the extent to which one has a pervasive, enduring though dynamic feeling of confidence that (1) the stimuli deriving from one's internal and external environments in the course of living are structured, predictable and explicable; (2) the resources are available to one to meet the demands posed by these stimuli; and (3) these demands are challenges, worthy of investment and engagement" (Antonovsky, 1995, p. 34). It is made up of three components: Comprehensibility: the extent to which a person perceives the incoming information as coherent and orderly, connected with the feeling that events are predictable and understandable. It is the ability to understand and evaluate the reality from the cognitive point of view. Manageability: the extent to which a person perceives the available resources (e.g., the network of support, faith in God) as sufficient to meet the requirements he or she faces. This component refers to the person's capabilities when confronted with stress. Meaningfulness: it is connected with the feeling that life is meaningful and life requirements are worth the effort and energy. It is the emotional-motivational component of the sense of coherence (Zadworna-Cieślak \& Ogińska-Bulik, 2011).

This is an approach to health which - unlike the popular pathogenic model emphasizes the maintenance of well-being, not the treatment of a disease. The basic problem underlying this model is the question of how individuals stay healthy despite the ubiquitous stressors (Antonovsky, 1995; Zboralski et al., 2010). People with a high sense of coherence are able to correctly and accurately assess the surrounding world. The occurring events are not surprising for them, they do not give up, and in difficult situations they are able to cope or they know where to look for help or support. They do care about something in life, there is something they find worthwhile and want to put their effort in. Such people respond to stressors in an active way, believing that the resources they have are valuable, effective, and useful in overcoming the difficult situation. Therefore, their emotions are not extreme and controllable, because tension does not automatically lead to distress and does not block the mechanism of coping in difficult situations. Hence, such people less often apply irrational defense mechanisms, and they try to rationally concentrate on the task instead (Antonovsky, 1995).

A. Antonovsky (1995) argued that a person's sense of coherence was the main factor to determine their ways of coping with stress. The higher the sense of coherence, the better coping in stressful situations. With this theoretical 
background, it was assumed in the study that adolescents' sense of coherence would be related to the ways of coping with stress they choose (Antonovsky, 1995). Coping styles were operationalized on the basis of classification by N. S. Endler and J. D. A. Parker $(1992,1994)$. The theory is based on the interactive model of understanding stressful situations by R. Lazarus (Lazarus, 1986). The way humans behave in specific situations is the result of conscious interaction of the situation and the person's coping style. R. Lazarus (1993) identifies two ways of coping with stress. The first is task-oriented (the person aims to solve the problem), and the other is emotion-oriented (the person aims to reduce the emotional tension). N. S. Parker and J. D. A. Endler (1992) added one more type of behavior in a stressful situation: avoidance.

It seems, then, that the selected research problem meets the public demand and refers to current research in the area of education and psychology of health. The work also fills the gap in the area of determinants of behavior in stressful situations, mainly occurring due to the scarce data connected with individual context. Moreover, most psychosocial studies on the sense of coherence focus on adults (Kasperek-Zimowska \& Chądzyńska, 2011; Rynkiewicz-Andryśkiewicz et al., 2014). Therefore, the present work deals with adolescents. The period of adolescence is regarded as very stressful because of many changes the young person faces. New challenges appear during to the transition into adulthood, such as gradual achievement of independence and self-identity. The major areas of stress for adolescents are school, family, and peer relationships. In problem and conflict situations, youths often display volatility and uncertainty of which course of action to choose. Coping with various tasks of the period of adolescence requires psychosocial maturity, i.e. the ability to tackle and solve problems, but also emotional maturity, expressed in resistance to stress or the ability to autonomously face life dilemmas (Kielar-Turska, 2000; Oleszkowicz, 1993).

\section{Aim of the research}

The aim of the work is to find out the relationship between the sense of coherence and the styles of coping with stress in the studied sample, and to identify the differences in the sense of coherence and styles of coping with stressful situations between girls and boys. The results of a study carried out by Płaczkiewicz \& Tucholska (2009) among adolescents lead to the following research hypotheses: the sense of coherence correlates positively with problemfocused coping strategies and the pursuit of social contacts, and negatively with emotion-oriented coping. 


\section{Participants}

The participants were 149 adolescents of both sexes, aged 14-17 (M=14.45). The study was carried out in junior high schools in Białystok. Most of the respondents $(59.7 \%)$ were girls $(\mathrm{N}=89)$, compared to $40.3 \%$ boys $(\mathrm{N}=60)$. The data obtained in the study shows that the respondents' age ranged from 13 to 17 years. The biggest group was people aged $14(55 \%)$ and $15(33.5 \%)$, followed by 13 -year-olds $(5.4 \%)$. The least numerous groups were respondents aged 16 (4 $\%)$ and $17(2.1 \%)$. The presented research is a pilot study.

\section{Statistical analyses}

Analysis of correlations demonstrated a directly proportional relationship (for indices $>0$ ) and a reversely proportional relationship (for indices $<0$ ) between the variables. The strength of relations was interpreted as follows: $\mathrm{R}>0.5-$ strong correlation, $\mathrm{R}$ between 0.3 and 0.5 - moderate correlation, $\mathrm{R}$ between 0.2 and 0.3 - weak correlation, and $\mathrm{R}<0.2-$ no or negligible correlation.

\section{Research tools}

1. The sense of coherence (SOC) was tested using the Life Orientation Questionnaire (SOC-29). It comprises 29 statements divided into three subscales - comprehensibility (COM), manageability (MAN) and meaningfulness (MEA). The first subscale includes 11 statements, the second, 10, and the third, 8 . The respondent chooses the responses using a 7point Likert scale (1 means "always", 7 means "never"). The global score (SOC-29) shows the level of the respondent's sense of coherence (the score may range from 29 to 203).

2. Coping Inventory for Stressful Situations (CISS) comprises 48 statements used to find out what coping strategies the person chooses in stressful situations. It identifies three basic styles of coping in a stressful situation: 1) task-oriented coping (TOC) assumes intentional and resolute focus on solving the problem and an attempt to make changes in a situation perceived as stressful; 2) emotion-oriented coping (EOC) involves emotional responses, such as being self-absorbed, daydreaming, or blaming oneself; 3) avoidance-oriented coping (AOC) assumes activities aimed at avoiding the problem, escape from the problem without attempting to solve it. It may take two forms: attempts to forget about the stressful situation by engaging in another activity - distraction (DIS), or looking for contacts with other people - social diversion (SOD). The respondent uses a 5-point scale to 
decide how often he or she takes up the activity in difficult and stressful situations.

\section{Differences in the sense of coherence and coping styles between girls and boys}

The results of maladjusted adolescents in the SOC-29 ranged from 70 to 180 points, with the mean of 121.92 in the sense of coherence scale, 43.69 in the comprehensibility scale, 43.21 in the manageability scale, and 35.01 in the meaningfulness scale. In the Coping Inventory for Stressful Situations, the mean score for task-oriented coping was 56.66 points, for emotional-oriented coping, 51.74, avoidance-oriented coping, 56.01, distraction, 27.22, and social diversion, 18.40 .

Table 1 The results of Sense of Coherence Scale (SOC-29) and Coping Inventory for Stressful Situations (CISS)

\begin{tabular}{|c|c|c|c|c|c|c|c|c|c|c|}
\hline & \multicolumn{4}{|c|}{ Youths N=149 } & \multicolumn{2}{c|}{ Girls } & \multicolumn{2}{c|}{ Boys } & \multicolumn{2}{c|}{$\begin{array}{c}\text { Significance of } \\
\text { differences }\end{array}$} \\
\cline { 2 - 12 } & Min & Max & M & SD & M & SD & M & SD & t & $\mathrm{p}$ \\
\hline TOC & 16 & 80 & 56.66 & 12.76 & 56.82 & 12.62 & 56.43 & 13.07 & 0.180 & n.i. \\
\hline EOC & 16 & 80 & 51.74 & 14.68 & 51.86 & 14.91 & 51.56 & 14.45 & 0.122 & n.i. \\
\hline AVC & 20 & 80 & 56.01 & 13.01 & 56.62 & 13.12 & 55.10 & 12.91 & 0.702 & n.i. \\
\hline DIS & 8 & 40 & 27.22 & 7.18 & 27.51 & 7.25 & 26.80 & 7.10 & 0.599 & n.i. \\
\hline SOD & 5 & 25 & 18.40 & 4.86 & 18.58 & 4.99 & 18.13 & 4.69 & 0.554 & n.i. \\
\hline SOC & 70 & 180 & 121.92 & 18.21 & 119.94 & 17.74 & 124.86 & 18.66 & -1.611 & n.i. \\
\hline COM & 18 & 65 & 43.69 & 8.47 & 41.87 & 8.31 & 46.40 & 8.03 & $-\mathbf{3 . 3 0 0}$ & $\mathbf{0 . 0 0 1}$ \\
\hline MAN & 19 & 64 & 43.21 & 7.74 & 42.67 & 7.59 & 44.01 & 7.96 & -1.038 & n.i. \\
\hline MEA & 17 & 56 & 35.01 & 8.15 & 35.39 & 8.05 & 34.45 & 8.33 & 0.691 & n.i. \\
\hline
\end{tabular}

Bold: statistically significant differences $\mathrm{p}<0.05$

Analysis using the t-Student test for independent samples showed that boys $(M=46.40 ; S D=8.03)$ differed significantly from girls $(M=41.87 ; S D=8.41)$ in terms of comprehensibility $(\mathrm{COM}) ; \mathrm{t}(149)=-3.30 ; \mathrm{p}<0.05$. The mean for boys is statistically significantly higher than for girls. This means that in the studied sample boys perceive the received information as more coherent and orderly, they have a higher sense of comprehensibility (COM).There are no statistically significant differences in the compared groups in terms of the sense of coherence (SOC) and its other components, manageability (MAN) and meaningfulness (MEA). There are no statistically significant differences, either, in the scores achieved in scales of task-oriented coping (TOC), emotion-oriented coping 
(EOC), avoidance-oriented coping (AVC), distraction (DIS) or social diversion (SOD).

\section{Analysis of relationships between the sense of coherence and styles of coping with stress}

The aim of correlation analysis is to answer the question whether the level of the sense of coherence is related to the styles of coping with stress in the studied sample. Table 2 presents paired correlations between global sense of coherence and its components and the strategies of coping with stress.

Table 2 Correlation coefficients (Pearson's r) of the sense of coherence and styles of coping with stress among adolescents

\begin{tabular}{|c|c|c|c|c|}
\hline & $\begin{array}{c}\text { SOC } \\
\text { Sense of } \\
\text { coherence }\end{array}$ & $\begin{array}{c}\text { COM } \\
\text { Comprehensibility }\end{array}$ & $\begin{array}{c}\text { MAN } \\
\text { Manageability }\end{array}$ & $\begin{array}{c}\text { MEA } \\
\text { Meaningfulness }\end{array}$ \\
\hline $\begin{array}{c}\text { TOC Task-oriented } \\
\text { coping }\end{array}$ & $0.22^{* *}$ & $0.26^{* *}$ & 0.12 & 0.09 \\
\hline $\begin{array}{c}\text { EOC Emotion- } \\
\text { oriented coping }\end{array}$ & $-0.32^{* *}$ & -0.01 & $-0.35^{* *}$ & $-0.36^{* *}$ \\
\hline $\begin{array}{c}\text { AVC Avoidance- } \\
\text { oriented coping }\end{array}$ & 0.13 & $0.19^{*}$ & 0.05 & 0.03 \\
\hline DIS Distraction & -0.00 & 0.13 & -0.05 & -0.10 \\
\hline SOD Social diversion & $0.30^{* *}$ & $0.24^{* *}$ & $0.22^{* *}$ & $0.22^{* *}$ \\
\hline
\end{tabular}

*. Correlation significant at the level of 0.05 (bilaterally)

**. Correlation significant at the level of 0.01 (bilaterally)

In adolescents the global sense of coherence (SOC) and comprehensibility (COM) were significantly positively correlated with task-oriented coping (TOC). In other words, as the index of task-oriented coping with stress grows, the global sense of coherence and comprehensibility also grow, i.e., the person perceives the incoming information as coherent and orderly. He or she feels that events can be predicted and understood and has the ability to understand and evaluate the reality from the cognitive point of view. A person with a high sense of coherence and comprehensibility more often copes with stress by doing tasks and aims to solve the problem by means of cognitive transformations or attempts to change the situation.

Emotion-oriented coping (EOC) was negatively correlated with the global sense of coherence (SOC), meaningfulness (MEA) and manageableness (MAN). It means that as the global sense of coherence and its two components grow, the index of using emotion-oriented coping lowers. In other words, in a stressful situation the person does not concentrate on their own emotions such as irritation, anger, or tension. 
There was a positive correlation between global sense of coherence (SOC) and its three components and social diversion (SOD) as a coping strategy. This means that global sense of coherence and its components are related with the tendency to avoid stressful situations by social diversion. The analysis of relationships between the variables showed that avoidance-oriented coping was positively correlated with comprehensibility. This means that as this component grows, the index of avoidance-oriented coping also grows.

The analysis of relationships between global sense of coherence including its components and distraction as the style of coping did not show any statistical significance between the variables. Analyzing the value of coefficients, it is worth stressing that none of them exceeded 0.40 , which proves moderate or weak strength of correlations between the analyzed variables.

\section{Discussion}

The objective of the presented study was to demonstrate relationships between styles of coping with stress and the sense of coherence in adolescents. Statistical data analysis showed the existence of covariance between styles of coping with stress measured by CISS and the global sense of coherence and its components measured by SOC-29. The results of the study confirmed the hypothesis that global sense of coherence is positively correlated with taskoriented coping and social diversion, and negatively with emotion-oriented coping. Comprehensibility is positively correlated with task-oriented coping, avoidance-oriented coping, and social diversion. Manageability and meaningfulness correlate positively with social diversity and negatively with emotion-oriented coping. Similar results were obtained in a study on adolescents by B. Płaczkiewicz and S. Tucholska (2009).

Hence, it seems that a person with a high sense of coherence more often assesses the stressor as more positive, less conflictogenic or less threatening than does a person with a low sense of coherence. Such a person has the underlying belief that everything will be all right, that he or she has the needed resources, that whatever is incomprehensible will become comprehensible, and that he or she has the right potential to reduce the tension. This belief itself is a great resource (Antonovsky, 1995).

The results of the research indicate that the sense of coherence has a positive impact on positive coping with stress. According to Woynarowska (2013), the higher sense of coherence, the higher chance of moving toward "health" along the continuum, as the easier it is to avoid threats and dangers. The results of the research show that adolescents with a higher sense of coherence more often choose task-oriented coping, and less often, emotion-oriented coping. As the sense of coherence grows, the index of emotion-oriented coping lowers. We may 
attempt to conclude that the sense of coherence can be treated as the "potential" which makes it possible to activate the appropriate strategies of coping in stressful situations in adolescents.

The analysis of data presented in the tables shows that the comparison of groups with the t-Student test did not demonstrate any statistically significant differences between girls and boys in terms of coping with stress and the level of sense of coherence and its two components. The obtained results lead to a conservative conclusion that although during adolescence boys and girls face different tasks, the analyzed variables do not differ.

In the face of the obtained study results, it seems that it is important to develop the sense of coherence among adolescents, which may promote constructive strategies of solving stressful situations. According to Antonovsky (1995), the process of socialization is very important in this regard. Personal experience is formed in the course of interactions with the environment. The development of the sense of coherence can begin even in early childhood and it settles at a level specific for the person in early adulthood (around 30 years of age), once the person has achieved some stabilization in life, when experiences from childhood and adolescence are consolidated or reversed. The development is promoted by life experiences, particularly including three properties: coherence of experiences, balance between overloading and underloading, and participation in decision-making (Woynarowska, 2013). Coherence refers to the extent to which the new experience fits the previous of current experiences of the individual. The more they make a logical entirety, the less often the occurring events are perceived as unexpected and surprising. The balance between overloading and underloading is kept if the requirements of life are adjusted to the person's abilities, age, strength, and health status. Participation in decisionmaking forms the sense of meaningfulness. It is important that the person takes an active part in creating the reality, takes the responsibility for the tasks received, and agrees to carry them out. This way, the individual forms the sense of participation, involvement and autonomy (Antonovsky, 1995; Worsztynowicz, 2013). Well-developed sense of coherence motivates the person to act. During the activity, resources or cognitive schemes and competencies are activated that may help reduce the activity of stressors, evaluate them as positive stimuli, or as stimuli that activate the regulatory mechanism. A person with high sense of coherence is more likely to respond to a stressor in an active way and with the conviction that the resources he or she has are valuable and effective in the situation. Therefore, his or her emotions are not extreme and still controllable, because tension does not automatically lead to distress and does not block the mechanism of coping in difficult situations. Hence, such people less often apply irrational defense mechanisms, and they try to rationally concentrate on the task instead (Terelak, 1999; Antonovsky, 1995). 
Clearly, education and support activities are needed that would be appropriate for adolescents and aimed at building the sense of coherence. They could lead to a higher level of the sense of coherence, and as a result, to increased application of task-oriented coping or social diversion and less emotion-oriented coping.

\section{Conclusions}

1. The sense of coherence and its two components (manageability and meaningfulness) did not significantly differ between the compared groups.

2. Boys significantly differ from girls in terms of comprehensibility. Comprehensibility is higher among boys than among girls.

3. There were no statistically significant differences between girls and boys in terms of scores in task-oriented coping, emotion-oriented coping, avoidanceoriented coping, distraction and social diversion scales.

4. The sense of coherence and styles of coping with stress correlate in the studied sample as follows:
a. Among adolescents the sense of coherence and its components (comprehensibility, meaningfulness) are positively correlated with task-oriented coping.
b. The sense of coherence, manageability and meaningfulness correlate negatively with emotion-oriented coping.
c. Comprehensibility is positively correlated with avoidance-oriented coping.
d. The sense of coherence and its components (comprehensibility, manageability, meaningfulness) are positively correlated with social diversion.

\section{References}

Antonovsky, A. (1995). Rozwikłanie tajemnicy zdrowia. Warszawa: Fundacja IPN.

Dolińska-Zygmunt, G. (2001). Orientacja salutogenetyczna w problematyce zdrowotnej. Model Antonovsky'ego. In: Dolińska-Zygmunt, G. (Eds.) Podstawy psychologii zdrowia. Wrocław: Wydawnictwo Uniwersytetu Wrocławskiego.

Endler, N. S., \& Parker, J. D. A. (1994). Assessment of multidimensional coping: Task, emotion and avoidance strategies. Psychological Assessment, 6.

Endler, N. S., \& Parker, J. D. A. (1992). Multidimensional assessment of coping: A critical evaluation. Journal of Personality and Social Psychology, 58 (5), p. 844-854.

Kasperek-Zimowska, B., \& Chądzyńska, M. (2011). Poczucie koherencji i style radzenia sobie ze stresem wśród rodziców dorosłych dzieci z rozpoznaniem schizofrenii. Psychiatria Polska 45 (5), p. 643-652.

Kielar-Turska, M. (2000). Rozwój człowieka w pełnym cyklu życia. In: Strelau, J. (Eds.) Psychologia. Podręcznik akademicki. Tom I, Gdańsk: GWP. 
Kosińska-Dec, K., \& Jelonkiewicz, I. (1997). Poczucie koherencji a style radzenia sobie, Psychologia Wychowawcza, 3, p. 217-224.

Lazarus, R. S., \& Folkman, S. (1984). Stress, appraisal and coping, New York: Springer.

Lazarus, R. S. (1986). Paradygmat stresu i radzenia sobie. Nowiny Psychologiczne, 3, p. 2-39.

Lazarus, R. S. (1993). Coping theory and research: Past present and future. Psychosomatic Medicine, 55, s. 234-247.

Oleszkowicz, A. (1993). Przebieg kryzysu adolescencyjnego w aspekcie przezwyciężenia niezgodności między celami a możliwościami jednostki. In: Oleszkowicz, A. (Eds.) Adolescencja. Wybrane aspekty rozwojowe $i$ wychowawcze. Ujęcia teoretyczne $i$ empiryczne weryfikacje, Wrocław: WUW.

Płaczkiewicz, B., \& Tucholska, S. (2009). Poczucie koherencji a zachowania zaradcze młodzieży. Studia Psychologica 9.

Rynkiewicz-Andryśkiewicz, M., Andryśkiewicz, P., Curyło, M. \& Czernicki, J. (2014). Analiza przydatności oceny poziomu poczucia koherencji $\mathrm{w}$ chorobach somatycznych i psychicznych. Medical Review, nr 4, p. 365-374.

Terelak, J. F. (1999). Psychologia menedżera. Warszawa: Wydawnictwo Difin.

Worsztynowicz, A. (2013). Coaching a poczucie koherencji. Forum Oświatowe, vol 25, no 2 (49).

Woynarowska, B. (2013). Edukacja zdrowotna. Warszawa: PWN.

Zadworna-Cieślak, M., \& Ogińska-Bulik, N. (2011). Zachowania zdrowotne młodzieży uwarunkowania podmiotowe i rodzinne. Warszawa: Difin.

Zboralski, K., Gernand, A., Orzechowska, A., \& Talarowska, M. (2010). Poczucie koherencji i strategie rozwiązywania problemów u pacjentów z rozpoznaniem trądziku różowatego i depresji - badania porównawcze. Postępy Dermatologii i Alergologii, T. 27, nr 2, s. 90-95. 